\title{
PRINCIPLES OF UNITY IN NOORDIN HASSAN'S "1400"
}

\section{(Prinsip Kesatuan dalam “1400” Noordin Hassan)}

\author{
Rohani Md. Yousoff \\ rohaniyousoff@gmail.com
}

\author{
Universiti Malaysia Terengganu. \\ 21030 Kuala Terengganu, \\ Terengganu, Malaysia.
}

\begin{abstract}
Man's responsibilities extend from himself to the people around him, the community and the environment. This article will identify such responsibilities based on al-Faruqi's principles of unity to further ascertain Islamic elements either through the decisions and actions of the characters featured in the play "1400" by Noordin Hassan, especially through its main character, Dolah. The intention (niyah) of Dolah when he decides and acts based on his weaknesses which include jealousy and greed. But at last Dolah becomes conscious of the error of his ways which then leads him away from evil to goodness, alluding to the story of the holy Prophet's own Hijrah. In "1400" Noordin Hassan delivers the message of Islam as his responsibility and duty as a Muslim, to seek knowledge in order to acquire wisdom for himself and for other Muslims through the gracious manner of theatre.
\end{abstract}

Keywords: principles of unity, responsibilities, “1400”, al-Faruqi, Noordin Hassan

\section{Abstrak}

Tanggungjawab manusia termasuklah terhadap dirinya dan orang di sekelilingnya, komunitinya dan juga persekitarannya. Makalah ini mengenal pasti tanggungjawab ini berdasarkan prinsip kesatuan al-Faruqi untuk menentukan elemen Islam melalui keputusan dan tindakan watak utamanya, Dolah, dalam drama "1400" oleh Noordin Hassan. Dengan niat atau secara sengaja Dolah mengambil keputusan dan bertindak mengikut kelemahan diri, iaitu sifat cemburu dan tamak. Namun, pada akhirnya Dolah sedar akan kesilapannya dan keluar daripada kejahatan kepada kebaikan yang 
MALAY LITERATURE VOLUME 29 NUMBER 2 DECEMBER 2016

menandakan perubahan, tamsilan kisah hijrah Rasulullah SAW. Dalam "1400" Noordin Hassan menyampaikan mesej Islam yang menjadi tanggungjawab dan tugas setiap Muslim dalam usaha mencari kebijaksanaan untuk diri sendiri dan juga Muslim yang lain menerusi teater.

Kata kunci: prinsip kesatuan, tanggungjawab, 1400, al-Faruqi, Noordin Hassan

\section{INTRODUCTION}

Noordin Hassan wrote pantomimes for the International Qur'an Reading Competitions (Musabaqah al-Qu'ran Antarabangsa) from 1976 to 1985 (Noordin, 1996:364). One of the pantomimes that he wrote was on the migration of the holy prophet to Yathrib, later called Madinah al-Nabiyy. This marks the first day of the first month of the Islamic calendar of Hijrah (al-Faruqi, 1986: 124). The research that he did in preparation for writing this pantomime implanted a seed in Noordin's mind from which "1400" was developed into a play. It took him one year to complete this play. It was first staged in Kuala Lumpur in 1981 (Noordin, 1996:364). Faizal Yamimi Mustaffa's translated text, published in 1998, is used as reference in this paper.

The issue of responsibility begins with man's duty towards himself which then extends to the people around him including his family and his community. On a wider scale, man is also responsible for the environment and the care of land and water. This responsibility is the divine trust (alamanah) offered to man. To uphold this responsibility man must understand and practise the principles of unity. Noordin uses the negative aspects of the play's main character to bring about realization and catharsis, hence a cleansing of the soul which produces a positive effect on the audience, through the process of reaction. He has used Dolah as a catalyst to bring out the reaction from the audience, as he has defined in his concept of theatre of faith. To make that realization more effective, Noordin lets the punishment be immediate and makes it happen on stage.

The seventh National Laureate (Sasterawan Negara), Dato' (Dr.) Noordin Hassan is well-known for bringing out Islamic elements and teachings through his dramas based on the holy Qur' an. Noordin defines the parameters of his play when it opens with dhikr (invocation or supplication) which opens the way for the narrator who begins with Bismillah, "In the name of Allah" (Faizal, 1998:250) with greetings to the audience, clearly stating the message of the play, which is "to make hijrah" (ibid). Noordin admits that 
of all his plays, " 1400 " is seen as didactic since the propagation of Islam is more evident here, in the elements used as catalysts to remember Allah SWT (2002:186). In selecting a wayang kulit ensemble (Kementerian, 2003:10) to support the performance, Noordin juxtaposes traditional elements with an obvious religious message suggesting at the same time that good intention (niyah) can be balanced with wise judgement. Apart from the lyrical lines, dhikr and invocations, the visual effects of Dolah praying, of the ratit saman are most effective in reinforcing the attributes of Islam. Combined with the traditional elements, the effect is a mix of Malay and Islamic identities.

It is not merely ideas that spring into Noordin's mind that are woven into his dramas but a combination of a sound understanding of Islam and traditional elements supported by a rich cultural heritage. What is interesting about any art form is the ways in which these options, or parameters, are used. While others may be imposed by rules of genre, style or mode, Noordin defines his parameters with a clear vision of his purpose which has become his mission. "1400" is Noordin's paradigm shift in consciously injecting Islamic elements in his plays since he began writing pantomimes for the International Qur'an Reading Competitions. Noordin realized that as a born Muslim, he had not delved deeper into the study of Islam. Like most Malays who are born Muslims Noordin believes that in being given the freedom to choose, man's fault and misfortune often lie within himself, and is not a result of Allah's SWT divine decree.

\section{CONCEPT}

The framework for analysis of this study is based on Ismail R. Faruqi's (1989) five principles of unity: unity of Allah SWT, unity of creation, unity of truth and unity of knowledge, unity of life, and unity of humanity. This framework is used as there are parallelisms of these principles in the themes and messages of the plays. This is especially so in the tawhidic sense, which is the essence of Islam. A keen reader of al-Faruqi, Noordin's plays were written before he "discovered" the works of al-Faruqi. But his ideology is in line with al-Faruqi, mainly because of the common ground in the understanding of the purpose of life. Working towards the goal of returning to Allah SWT, human beings have a responsibility in life towards improving himself as well as to care for others and the environment for the sake of completing the cycle of life to suit the sunan (pattern) of Allah's SWT creation. Whilst al-Faruqi explains his principles in the form of theological books, Noordin 
expresses his philosophy and concerns in the form of theatre. However, both have similar missions which they pursue in different ways.

\section{FIVE PRINCIPLES OF UNITY}

The first principle of unity is that Allah SWT is the first and ultimate cause and end of everything. When truly guided by this principle, humankind will not make the mistake of believing falsehoods and in false gods. The second principle is that everything in the cosmos and every event that takes place, does so by His command to serve a purpose, subject to other purposes which end only in Allah SWT. The subservience (taskhir) of creation to man knows no limit as everything on earth can be used (not abused) by man to his advantage. Whenever a person is afflicted by some misfortune, it is necessarily the result of one or more of his own actions. The ultimate purpose of the individual is to return to the creator and this can only be achieved by searching and reaching for the truth.

The third principle is that truth (Surah al-Haqq) cannot be equivocal as what is taught through revelation (wahy) is true and must correspond to reality and agree with it. The truth begins with the Qur'an, as stated, "The revelation of the Book (this Qur'an) is from Allah, the All-Mighty, the AllKnower" (Surah al-Ghafir 40:2). Knowledge is perceived as true if you have a degree of wisdom and maturity of both religious and ethical vision and human beings have the capacity to acquire this wisdom. Knowledge is self-evident, acquired through common experiences and is capable of "ought-necessity". This means that the stark reality of life must be seen as it is, not by what one hopes for.

The fourth and fifth principles remind us that human beings in essence are equal. What really distinguishes one individual from another is his character. A person's superiority can therefore be seen only in terms of the degree to which a human being is honourable. The truly honourable human being is one who is god-fearing and who recognizes and fulfils the rights of god and his fellowmen.

\section{ANALYSIS}

Noordin Hassan uses symbols, metaphors and allusions as well as allegories from the Qur'an in conveying his message in "1400". These are done in a combination of oral and/or visual forms. The play is layered with Islamic invocations, movements and traditional music provided by a wayang kulit 
(shadow puppet) ensemble. To support the traditional elements, stock characters like Wak Long and Pak Dogol from traditional Malay theatre forms of wayang kulit and makyong are used as comic relief. Noordin's choice of traditional music, Islamic motifs and symbols lend visual and oral support to the main story structure. He also uses visual theatrical devices to heighten the supernatural scenes. Devices like mime and dance movements are used to visualize the dialogue being narrated hence producing visual and dramatic impacts. Water pollution is an issue that is highlighted here and the use of water as metaphors and symbols are strong throughout the play. A polluted river is used as the main setting in another play, Cindai, where the main character, Pak Ku, spends most of his life repenting for his sin (Noordin, 1997). Through the years Pak Ku sees how human beings have contaminated the river, a source of food for humankind.

Instead of using the structure of thematic progression, "1400" is cyclical. Visually, the set design under "Stage Setting" suggests that this play can be staged anywhere as the set is structured such that it will not define "any certain place or anything concrete" (Faizal, 1998:248-49) indicating that the story can happen to anyone at any time.

Al-Faruqi's thoughts on the five principles of unity will be examined in " 1400 " in relation to the condition and the choices made by the main character, Dolah. The cause and effect of Dolah's decision is seen as the cause of the undesirable consequences for him, the villagers and the environment. The wrong choice made by Dolah works as a catalyst that breaks the chains of unity, which are all part of the laws of nature. According to al-Faruqi these laws "... are the sunan (patterns) of Allah's SWT in His creation" (al-Faruqi, 1989: 36). This examination will be in line with the Qur'an and hadith.

In his role as a vicegerent of Allah SWT, Dolah's choice stems from one wrong choice of Dolah, the envier. Noordin uses Surah al-Falaq which is recited by Dolah in Scene XV. Dolah awakens, is shocked and begins to realize what he has done. He asks Allah SWT for forgiveness and asks to be blessed. He then recites the Surah al-Falaq (Scene XV). It reads:

Say: "I seek refuge with (Allah), the Lord of the daybreak, From the evil of what He has created,

And from the evil of the darkening (night) as it comes with its darkness;

And from the evil of those who practise witchcraft when they blow in the knots, And from the evil of the envier when he envies". 
This verse depicts the envy of every human being who measures his position in life against the material success of another. Dolah does not see this as a test of his faith. Allah SWT has ordained, "No person shall have a burden laid on him greater than he can bear" (Surah al-Baqarah 2:233) and the burden of poverty and lameness is but His test on Dolah.

"Dolah", short for Abdullah, literally means servant of Allah SWT. Dolah represents every man who is put to the test. His first test is his physical disability. Apart from being lame, his other tests are that he is poor and his mother is sick. Due to these adversities, his proposal of marriage to the village head's daughter is rejected and this elevates his anger. The last straw for Dolah is when he is not chosen to represent his people although he has helped them. Dolah has the right makeup of a man who is willing to fight for the rights of his people, but the people do not select him because he is lame and poor. The ones selected are dubious in character and this makes Dolah decide to change his life. Dolah does not see all these adversities as tests of his faith in Allah SWT. Despite Soud's caution about being hasty as they will be "used by other people", Dolah feels that he is the one who is being used and wants to do things his own way. Dolah sees that the only way to get anywhere is to be rich and he does not care how he does it. His line, "I also want to be rich" $(1400,1998: 254)$ comes from envy.

The metaphor of the "lameness" of Dolah is his scepticism about the will and power of Allah SWT. In fact, Dolah blames Allah SWT for his situation. This is evident in the following dialogue: I did not ask to be poor. I'm a pauper. Is it my mistake that I'm lame? God made it so and my situation made it worse (1400, 1998:255).

In his desire to change his situation, Dolah feels that if he has money then he will be respected $(1400,1998: 256)$. From this "evil of the envier" other evils set in. The next evil is to seek help from the pawang or witch doctor $(1400,1998:$ Scene V) that is "... the evil of those who practise witchcraft when they blow in the knots". He takes the amulet from his late mother's waist and seeks help from the witch doctor. It is his envy of the rich and successful that has caused him to distance himself from Allah SWT. Dolah chooses to make the change for himself, with the help of another other than Allah SWT.

\section{THE FIRST PRINCIPLE OF UNITY}

Dolah violates the first principle of unity, which is the unity of Allah SWT by seeking the help of a witch doctor to get rich. This is the principle of 
tawhid-al-uluhiyyah, which is the "Oneness of the Worship of Allah" as "... none has the right to be worshipped" but Allah SWT (al-Hilali and Khan: 892). This means that in everything that Muslims do, from praying, appealing to and asking for help, it is directed only towards Allah SWT and no other sources, such as the unseen, as even these are creations of Allah SWT. To swear by, to offer sacrifice, should be in the name of Allah SWT; to do good, to be charitable, to fast or perform the pilgrimage, is in the Name of Allah SWT. When truly guided by this principle, man will not make the mistake of believing in falsehoods and false gods.

On one of his hunting trips, Dolah is rammed by a wild boar. When he is injured the dukun (Scene XII) calls on the ancestors of the river, Jungle and animal to cure Dolah. He proclaims Dolah as "the master" of all: the village, the estate, the river and the jungle. The dukun appeals to the ancestors to speak to the "people above the wind," not to Allah SWT. Here the unity of Allah SWT is again broken, since the reliance is on the ancestors to cure Dolah. The dukun makes the same mistake in seeking the help of several ancestors.

Noordin stresses the importance of the unity of Allah through the dialogue of the Maulana who reminds Dolah: "Allah said that there is no God but Him" (1400, 1998:256). When Dolah says, "If the leg is not lame I can dance; If the pocket is full of money I can enjoy" (1400, 1998:256), the Maulana reminds Dolah: "But look to the guidance of the al-Qur'an, and open your hearts. Straighten your faith as you have been commanded; do not follow your base instincts" (1400, 1998:256).

But Dolah does not listen to the advice of the Maulana or the constant reminder by his friend Soud about praying. Their advice reinforce the principle of the unity of Allah SWT.

Noordin uses visual effects to highlight the fact that Dolah's choice is wrong. In the stage directions, the Jinni appears with the devil's fork. Noordin writes, "Lightning, thunder, lightning, thunder. Strong winds. Shrieking sounds, long, forlorn, far away. The night is maddening" (1400, 1998:259). It is as if nature screams at the atrocity of Dolah's action of dragging his mother's corpse to bury it under the house. Noordin is suggesting, perhaps, that despite signs often seen in the changes in nature, human beings will ignore them to attain material gains at the expense of disorder. These lines and visuals affirm al-Faruqi's first principle of the unity of Allah SWT. Dolah's act of seeking help from the witch doctor and his reliance on the Jinni to give him wealth accelerates the breaking of the other chains of unity. As stated in the Qur'an: Had there been therein (in the heavens and 
the earth) alihah (gods) besides Allah, then verily both would have been ruined (Surah al-Anbiya'21:22).

As a rich man whose source of wealth is other than Allah's SWT bounty, Dolah creates chaos and harms all those around him and eventually his own lineage. In making one wrong choice, Dolah creates havoc as the laws of nature and the unity of creation are disrupted. The most significant is Dolah's abuse of the land. Money has allowed Dolah to get anything he wants. He buys all the village land, "As far as the eye can see" (1400, 1998:267).

When Dolah distances himself from Allah SWT he forgets that as a human being he was offered the divine trust. He forgets the mithaq (covenant) made with Allah SWT; the divine trust which also means caring for other human beings. The play demonstrates that the principle of the unity of Allah SWT is broken due to a wrong choice, a choice which is not guided by the Qur'an. This, in turn, breaks the chain of unity of creation as the environment is abused. Then the unity of life and the unity of humanity are also broken, with disastrous results for the human race because of Dolah's abuse of the land and the river. In disregarding nature and other people, man does not realise that what he does to others will come back to hit him. As stated in the Qur'an, "Whosoever does a good deed, it is for his own self, and whosoever does evil, it is against (his own self)" (Surah al-Jathiyah 45:15).

\section{THE SECOND PRINCIPLE OF UNITY}

The second principle of unity, which is the unity of creation, is that everything in the cosmos and every event that takes place does so by His command. All things are created to serve a purpose and all purposes are inter-related. This purpose is subject to other purposes which end only in Allah SWT. When Allah SWT offers al-amanah (the divine trust) to man, it includes the trust of moral responsibility (Surah al-Ahzab: 72). This responsibility extends to the care of Allah's SWT other creations which include the earth and other living things. From land and water come provision for food to sustain human beings. The subservience (taskhir) of other creations to human beings knows no limits. This means that everything on earth can be used by humans to his advantage. It is necessary for nature's cycle to repeat itself, so that life can continue. This can only be achieved through the care of nature by human beings. Unfortunately, Dolah has abused this trust for his own benefit.

Dolah's act of turning the land area into stables for his horses results in disaster for the villagers. Dolah desecrates the river which is a source of food for the people. The river is the clearest evidence of damage done to 
nature by Dolah. Water is mentioned sixty-three times in the Qur'an and the first to have existed wherein the Qur'an states, "And we made from water every living thing" (Surah al-Anbiya' 21:30). It is a source of sustenance and food (Surah al-Baqarah 2:22 \& Surah al-Ma'idah 5:96). Instead it becomes a bathing place for Dolah's horses. It is pointed out in the play that the river is " ... full of faeces. There are no more prawns and fishes in the ancestors' river" $(1400,1998: 268)$. The polluted river brings disease to the villagers. Noordin shows the extreme end of the damage done to nature. As Pak Dogol comments, "All new[-]borns are not like the ancestors' grandchildren anymore. They're ugly, disfigured, horrible; stupid, idiot ..." (1400, 1998: 268). Dolah does not care until his own child is born disfigured. As Mak Som describes the child to the audience, "He has a big head, long ears, tiny eyes, hairy body ..." $(1400,1998: 281)$. Dolah has done so much damage and ends his lineage when he throws his baby out in disgust (ibid).

Dolah breaks yet another rule when he hunts for sport, thus destroying life. In Islam, killing of animals for sport, not in the name of Allah SWT is forbidden unless they endanger you (Sahih Muslim, Vol. 4, Book 24). Killing is an abuse of life that breaks the chain and inter-relationship within the environment, an act that goes against the purpose of creation. Everything on earth from the smallest pebble to the largest mammal "..fulfills a purpose assigned to it by God, which is necessary for other beings" (al-Faruqi, 1992:55). Al-Faruqi says, "From the unity of Allah SWT, the unity of His creation follows with logical necessity" (1989:36). He also points out that this relationship between the elements and nature constitutes an integral part of the whole system which is open to inspection for human beings, if they take the trouble to see (al-Faruqi, 1989:39).

Under the principle of unity of creation, al-Faruqi says, "Between the objects of creation and human use of creation there is a built-in concordance" (al-Faruqi, 1989: 38). The natural environment created by Allah SWT is "... capable of being used by man for his nourishment, enjoyment and comfort" (ibid) not to be abused. As warned in the Qur'an, "And do not do mischief on the earth, after it has been set in order" (Surah Al-A'raf 7:56). Yet, Dolah ignores the warning by his wife Intan Siti Rahimah and continues to vandalize nature. The social environment often leads to destruction of the natural environment, as there is "concordance" between one and the other. According to al-Faruqi, "The truth, which is the object of reason, is embodied in the laws of nature" (1989:40). Dolah refuses to see that what he is doing is breaking the unity of creation as well as the unity of mankind 
when he ignores the divine trust bestowed on him. The wealth that Dolah has accumulated has gone to his head and he refuses to see the error of his ways, in the very same manner it influenced Qarun, as well as others in the present time.

\section{THE THIRD PRINCIPLE OF UNITY}

The third principle is the unity of truth and the unity of knowledge. The first kind of knowledge, revealed truth (Surah al-Haqq), cannot be equivocal as what is taught through revelation (Wahy) is true. The second, according to al-Attas is "acquired by man by means of his own effort of rational enquiry based on experience and observation" (al-Attas, 1984:74). However, knowledge must correspond to reality and agree with it. Revealed knowledge is perceived as true if you have a degree of wisdom and maturity of both religious and ethical vision and human beings have the capacity to acquire this wisdom. Acquired knowledge becomes self-evident, acquired through common experience and observation, and is capable of "ought-necessity." This means that the stark reality of life must be seen as it is, not by what one hopes for.

"Rahimah" is derived from "ar-Rahim," one of the names of Allah SWT which means "Merciful" or compassionate. As her name suggests, Intan Siti Rahimah is a compassionate human being who cares about the welfare of the villagers. The second wife of Dolah, she is the "jewel" (Intan) of goodness and used as a vehicle by Noordin as a contrast to Dolah's wrong-doings. Intan Siti Rahimah sees the truth from her observation, as it corresponds with the reality of the situation in the village. As she tells Dolah, "The villagers are talking about the stable contaminating the river. Their children are all sick" (1400, 1998:269). She confronts him about the living condition of the villagers, but Dolah refuses to acknowledge the truth, the stark reality of the damage he has done. Yet, in his heart he knows she is right, but he will not listen to his heart. When he finds out that she is pregnant, he stops her from going to the village, "And above all, don't eat fish, crab, prawn(s) from the village river" (1400, 1998:271). Intan Siti Rahimah's dialogue and action confirms al-Faruqi's unity of truth and the unity of knowledge when she looks for truth through observation and seeks change for the villagers. She understands very well the need of the people to be educated. Intan Siti Rahimah's awareness is juxtaposed against Dolah's refusal to search and reach for the truth. In fact, her compassion and concern for the villagers upset Dolah. Intan Siti Rahimah spends time helping the villagers and going 
to the musollah (small mosque) in her search for revealed truth (al-Haqq). Dolah denies her permission to teach the children as he feels that she will be wasting her knowledge. Teaching is an honourable profession and it is not enough to acquire knowledge, one must also impart it. The ultimate purpose of the individual is to return to the Creator and this can only be achieved by seeking and searching and through acquired knowledge, that is, education, reach for the truth.

A strong symbol used by Noordin is the gift of the Qur'an from Siti Rahimah (Scene XXI). This is in accordance with al-Faruqi's principle of the unity of knowledge, whereby the acquisition of knowledge must, on the first level, be the understanding of the unity of truth as revealed in the Qur'an (wahy). When Dolah accepts it, saying he will take it with him wherever he goes, he receives the Qur'an as the symbol of acceptance of faith and revealed knowledge. It would also appear that Dolah has acquired the knowledge from experience ( $\mathrm{ilm}$ ) to move towards his return journey to Allah SWT. Dolah earns an honest living and begins doing good deeds such as helping to build the mosque.

\section{THE FOURTH PRINCIPLE OF UNITY}

The fourth principle of the unity of life means that the free will endowed to humankind is to be exercised through the realization of moral laws. When offered the divine trust the choice to do good or evil depends totally on humankind. When Dolah allows his people to be sick he breaks the unity of life. Noordin emphasises the break in the cycle of life in a scene where Tipah is chased by the horse ghost, muttering to the doll she was dragging: Horse eats us. Horse eats our children. Horse will eat my child. If it eats my child, I'll have no child (1400, 1998:275).

When there are no children, it means the cycle of life is discontinued, asserting the importance of al-Faruqi's principle of unity of life. Tipah's worry about the loss of her child echoes Noordin's worry about the extinction of the human race. When Dolah throws away his disfigured child, it is his choice. When Dolah's child is born, Mak Som questions this punishment from Allah SWT, "Whose fault is it?" $(1400,1998: 280)$ is perhaps Noordin's reminder of the freedom of choice offered to humankind which is being abused. The result of this abuse can only end negatively. When Dolah kills animals for sport and throws out his child Dolah has discontinued the unity of life, thus affirming the need for the unity of life. In destroying one particle, the chain of purpose is interrupted, which is why hunting for sport is not permissible. 
Noordin uses the disfigured child to symbolise the damage Dolah has wreaked on nature. Unfortunately, his child suffers disfigurement as a result of his father's own doing suggesting perhaps, that our children and the future generations will suffer from our wrong choices and actions.

Apart from endowing man with free will, Allah SWT also gives guidance and the criteria (furqan or makhraj) in choosing between right and wrong (Surah al-Imran 3:4). Obviously Dolah knows how to differentiate right from wrong as he has a religious background $(1400,1998: 255)$ but he has made the wrong choice. Al-Birr (piety, righteousness) is the quality of one who believes in Allah SWT and is "... patient in extreme poverty and ailment (disease)" (Surah al-Baqarah 2:177). An ousted Siti Rahimah embodies this piety and righteousness when she earns a living making mats, using her knowledge of Islamic motifs as designs for the mats.

Noordin uses motifs of nature in the setting, like "wind, waves, dead trees" and a replica of the dead tree "which has fresh leaves" symbolizing the cycle of life and death. When Intan Siti Rahimah was chased out of the house and the village by Dolah, Mak Som relates that "there was heavy rain that night" (Scene XIV). Here Noordin uses rain which also portents disaster. As said in the Qur'an, water can cause destruction as in the floods that took place when Nuh's (Noah) people rejected him as a prophet (Surah al-Qamar 54:11,12), just as it drowned Pharaoh's “... gardens and springs" (Surah ad-Dukhan 44:24, 25). Noordin uses the visual symbol of the old woman and the young woman in the opening scene to forewarn the wrong choice to be made by Dolah, who was not guided by the Qur'an in making his choice. The symbol represents one person who has travelled through time, with choices guided by the Qur'an. This also symbolises the cycle of life. The young woman is the symbol of youth with "many paths to choose" but is guided by the Qur'an and begins the path of life with the right intention, that is, Bismillah, in the name of Allah. Only then, in the twilight years of a person's life, represented by the old woman, he or she has made the right choice.

\section{THE FIFTH PRINCIPLE OF UNITY}

The fifth principle of unity of humanity reminds us that human beings in essence are equal. What really distinguishes one individual from another is his character. A person's superiority can therefore be seen only in terms of the degree to which a human being is honourable. The truly honourable human being is one who is God-fearing and who recognizes and fulfils the rights of 
Allah SWT and the rights of his fellowmen. As stated in the Qur'an, “...He may test you which of you is best in deed" (Surah al-Mulk 67:2). Dolah's ill-acquired wealth is temporary as stated in the Qur'an, "Your wealth and your children are only a trial, whereas Allah! With Him is a great reward" (Surah al-Taghabun 64:15).

The question that Dolah asks of Intan Siti Rahimah, "Doesn't God ask us to get rich in the world too?" (Scene IX) is valid, but to what extent does Man go to get rich? Intan Siti Rahimah reminds him that wealth should be used "... for the cause of Allah. Not for wasting it and abusing other people." Dolah's extravagance embarrasses Intan Siti Rahimah. It saddens and shames her as Dolah does not use it in the cause of Allah SWT, but wastes it and abuses other people with it (Scene IX). How much is never enough for Dolah, or for humankind. The importance of zakat and charity is stressed in eighteen surahs in the Qur'an ${ }^{1}$ which clearly defines the need for every Muslim to be charitable. Charity is to be given to the poor and for Allah's cause. To cite one example from the Qur'an: (Charity is) for fuqara (the poor), who in Allah's cause are restricted (from travel), and cannot move about in the land (for trade or work) (Surah al-Baqarah 2:273).

As an employer of the villagers, Dolah is not being humane. In fact, he is blinded by his new-found wealth that he abuses his position as he is easily goaded by materialism and dazzled by falsehood. He is now called "Orang Di Kaya Pak Tuan Dolah" or The Rich Master Dolah, no longer Dolah the Lame. His behaviour makes Dolah an al-Musrifun (those who waste by extravagance) whilst the Qur'an encourages Man to follow the middle course, to practise moderation (Surah al-Isra' 17:26). Dolah's attitude highlights the need for social order in human societies for the unity of humanity to be realised.

Noordin also points out the importance of the principle of unity of humanity through the attitude of people towards the disabled as seen in Siti Rahimah's case in Scene XIX. No one goes near her as she is a leper, thus she covers herself with a shroud. In another play, Malam ini Penyu Menangis (Tonight the Turtle $\mathrm{Cries}^{2}$ ), Noordin documents the life of a poet, J.M. Aziz, who suffers from leprosy but sits by the sea, inspired by nature, by the wonder of Allah's creation (2000:133). Deformity does not mean despair, not for J.M. Aziz, not for Siti Rahimah. Not as long as they have faith in Allah SWT.

Dolah's situation worsens as the "evil" accelerates. Dolah has entered "... the evil of the darkening (night) as it comes with its darkness," as Dolah's 
heart is darkened by his new-found wealth and the power that money can buy. Dolah's personality and lifestyle have changed. This, according to al-Faruqi, is, "What develops out of habit and judgement, tendency and temperament ..." and these "... characteristics contribute to determining the human person" (al-Faruqi, 1989:47).

In return for his reliance on the Jinni, Dolah gets "a pot of gold which is full of jewels ..." (Faizal, 1995:164). In the original Malay text Dolah exclaims, "Harta karun; harta karun" when he sees the treasure (Noordin, 2002:162). Noordin uses the allegory of "Karun" or Qarun (Korah) refering to one of Moses' people mentioned in the Qur'an who was given great wealth, "And we gave him of the treasures, that of which the keys would have been a burden to a body of strong men" (Surah al-Qasas 28:76). But he was ungrateful to Allah SWT despite the warning not to be. In the following verse of the same surah, there is a reminder about apportioning wealth for "lawful enjoyment," and not to seek "mischief in the land" (Surah al-Qasas 28:77). All that wealth went to Qarun's head and he became arrogant.

Dolah, too, becomes arrogant and his new-found wealth is spent in unlawful enjoyment and this leads to mischief and damage to the land. He knows that the Jinni has stolen the gold and jewels that are buried by other people (Scene VI) and this is haram (unlawful), as stated in the Qur'an: O mankind! Eat of that which is lawful and good on the earth, and follow not the footsteps of shaitan (Surah al-Baqarah 2:168).

Yet Dolah does not care that the wealth brought by the Jinni is haram. He does not care that what he feeds on is unlawful and will contaminate his flesh. He comes to a stage where he gets so close to the Jinni and does not need the witch doctor as mediator. Dolah is disillusioned with mankind as he becomes more dependent on the Jinni who, he says, is "my friend, better than man" (Scene VI). Dolah befriends the Jinni who, "He (Allah) created from a smokeless flame of fire" (Surah ar-Rahman 55:15).

The situation worsens when Dolah hunts "Rats, cockroaches, lizards, frogs, women." Rats, cockroaches, lizards and frogs are dirty and inedible. Noordin is alluding to Dolah's dirtying himself spiritually as well as physically. The "hunt" for women is a sport often associated with the need of the flesh and the rich. As al-Faruqi points out, "The main corpus of religious or moral law consists of actual practices of living" (al-Faruqi, 1989: 43). As a vicegerent (khilafah) each human being has to ensure that his or her lifestyle is clean and must contribute to the development of society, which affirms the need for unity of humanity. 
Noordin uses the symbol of darkness as ignorance and light as a blessing bestowed by Allah SWT. As Dolah's heart is darkened by the evils he has brought upon himself and the environment, it is this "light" that makes Dolah "see," which cleanses his soul and gives him the power to overcome his handicap. Symbolically, Dolah is enlightened when he is no longer lame as he returns to Allah SWT. This is further heightened at the beginning of Scene IV when "five figures in black sheets (who) struggle from the darkness all around them" immediately after Maulana says, "Verily for those who have faith in Allah, He will put enlightenment in their hearts" in Scene III.

The break in the principle of unity of humanity is seen in the desire of the villagers to get rich quickly by selling off their ancestors' land to Dolah. Further evidence is seen in the two land agents, in the characters of $\mathrm{Abu}$ Lahab and his wife, who persuade the villagers to sell their land to Dolah so they can get rich as well. When the villagers agree to sell their land to Dolah through Abu Lahab, Noordin is perhaps commenting on how shortsighted the Malays are for selling the land of their ancestors to gain quick, easy money. This worry is reiterated through Mak Su's dialogue in another play, Anak Tanjung (Noordin, 2002:524). For their ignorance in allowing Abu Lahab and his wife to be brokers to sell their land to Dolah, the children and grandchildren of the villagers suffer, they shall become a "disfigured race, idiot race" $(1400,1998: 268)$. An "idiot race" is because they sell off the land of their ancestors for quick money; a "disfigured race" refers to their allowing worldly, carnal needs to be prioritized over the needs of the soul. On the other hand, the kindness of characters like Pak Long, who gives shelter to Siti Rahimah (1400, 1998:292), affirms the importance of the unity of humanity, of compassion between human beings to ensure the cycle of life continues.

In Scene XXIII, when Pak Long says that Siti Rahimah came, "In the darkness of the night ... now the sky is bright and beautiful ..." Noordin uses the symbol of water, darkness and light. When Siti Rahimah arrives at the village, it was dark and raining heavily, but she is enlightened. When she leaves the village to look for Dolah, she thanks Pak Long for the shelter and Dolah who has given her "that glass of water." As a man who sells drinks, Dolah here symbolizes the quencher of thirst. In offering her "that glass of water," he has also cleansed her. The fact that the villagers did not punish Abu Lahab and his wife as they repent and redeem themselves shows that the villagers have compassion. These acts of charity are selfless and contribute to the unity of humanity. 
After all, Allah SWT forgives even the worst of errors, as long as man does not associate Him with another. In comparison, is Dolah any less a hypocrite than Abu Lahab? Abu Lahab works openly as an agent, accumulating personal wealth from the sale of land by the villagers. In the ethics of intent, was Dolah's intention (niyah) genuine in helping the people, or was he hoping to be rewarded for it? When he does not get rewarded or recognized, Dolah gets angry and in the process forgets his duties as a Muslim. Dolah has the characteristics of the impatient man who needs to see immediate rewards. Noordin seems to allude to the hypocrisy of humankind that works under different guises when he is not guided by the Qur'an but by his passion which often results in severing the principle of unity of humanity.

Despite violating a serious aspect of tawhid, Noordin seems to say that Allah SWT accepts Dolah's repentance, as he was foolish in seeking the help of the witch doctor but repents. This can be supported by what is stated in the Qur'an:

Allah accepts only the repentance of those who do evil in ignorance and foolishness and repent soon afterwards; it is they whom Allah will forgive and Allah is Ever All-Knower, All-Wise.

(Surah al-Nisa' 3:17)

Repentance must be genuine and the mistake not repeated. Only then will Man's repentance be accepted. Dolah is genuine and he is a believer. As stated in the Qur'an, a believer is one with a self-reproaching spirit (Surah al-Qiyamah 75:2) that is, a spirit with a conscience and that engages in selfreproach which is perhaps a way to redeem sins, as Dolah's sins are redeemed.

Apart from sustenance, water also means Mercy, as stated in the Qur'an, "And it is He Who send the winds as heralds of glad tidings, going before His Mercy (rain)" (Surah al-Furqan 25:48). When Dolah is hallucinating and his mother appears, she begs him to remove her corpse from under the house and advises him to repent and seek forgiveness from Allah and "migrate." Before Dolah hallucinates at the beginning of Scene XV, the stage directions state that there is "lightning, thunder; sound of the wind," before Dolah sees the corpse of his mother and repents. Rain here signifies Dolah's awakening from a slumber of ignorance. Dolah is now cleansed from the "evils" committed. As stated in the Qur'an: 
(Remember) when he covered you with a slumber as a security from Him, and $\mathrm{He}$ causes water (rain) to descend on you from the sky, to clean you thereby and to remove from you the rijz (whispering, evil suggestions) of shaitan (Satan), and to strengthen your hearts, and make your feet firm thereby

(Surah al-Anfal 8:11)

Perhaps the nearest thing to "rain" that makes Dolah repent are the tears of a mother who says, "My soul is crying" (1400, 1998:283). As Noordin says, "A mother's love is based on fitrah. Often it is like blessed rain that falls on parched earth" (Noordin, 2002:190). It is his mother's love and his love for his mother that makes Dolah realize that what he has done is wrong, which draws out the conscience and recalls Man's covenant with Allah SWT. With repentance comes prayer. Water cleanses and the best form of cleansing is ablution. In the stage directions, Dolah is seen praying. Obviously this is done after ablution. As reported by Abu Huraira:

Allah's Messenger (PBUH) said: When a bondsman - a Muslim or a believer - washes his face (in the course of ablution), every sin he contemplated with his eyes will be washed away from his face along with the water, or with the last drop of water; when he washes his hands, every sin they wrought will be effaced from his hands with the water, or with the last drop of water; and when he washes his feet, every sin towards which his feet have walked will be washed away with the water, or with the last drop of water, with the result that he comes out pure from all sins.

(Sahih Muslim, Chapter XCVIX: 187)

Previously, despite advice from Maulana and Soud and even from opportunists like the Doctor and the Make-up Artist, to remind Dolah about prayers, and to take off his false leg and false eyelashes when he prays, Dolah ignored them all. As he said to Soud, what has prayer got to do with his situation? Indeed, as stated in the Qur' an, "Verily, as-salat (the prayer) prevents from al-fahsha (i.e. great sins of every kind)" (Surah Al- 'Ankabut 29:45).

By making all the characters around Dolah constantly remind him of prayer, Noordin seems to say that evil could have been avoided had Dolah resorted to prayer and patience. As stated in the Qur'an, "Truly! Allah is with the as-sabirin (the patient)" (Surah al-Baqarah 2:153). Humankind, represented in Dolah, is not patient and is quick to revert to associating 
Allah SWT with others for sources of income, even if the source is wrong. Noordin portrays Dolah as impatient, irritable, niggardly and not constant in prayer. These are the qualities of humankind as mentioned in the Qur'an:

Verily, man (disbeliever) was created very impatient;

Irritable (discontented) when evil touches him;

And niggardly when good touches him.

Except those who are devoted to Salât.

Those who remain constant in their Salât

(Surah al-Ma arij 170:9-23).

To uphold salah (prayer) is to be in constant remembrance of Allah SWT. Through this constant reminder, Man then will be good to himself, his fellow beings and the environment.

It was reported that the Holy Prophet had said, "Verily migration wipes out all the previous (misdeeds), and verily the pilgrimage wipes out all the previous (misdeeds)" (Sahih Muslim, Chapter LV: 83). When Dolah "migrates" he travels out of the village, into another village. He changes his typical way of living by selling drinks. More than a physical act, Dolah undergoes a paradigm shift, as he leaves the "evils" and goes through life doing good deeds and ibadah beginning with the right intention, trust and faith in Allah SWT. The experience of Dolah is an inward journey signifying the dignity in Man as he faces Allah SWT, in his return to his Creator, reaffirming the first principle of the unity of Allah SWT, and bringing the play to a complete cycle. Noordin uses the tower to symbolize the direction to take for every Muslim:

Many paths we had to choose

We asked ourselves which one to take

The soul of Hijrah points to the tower

$(1400,1998: 251)$.

When Dolah becomes conscious of his error it leads him away from evil to goodness, which is the key to the door of a virtuous circle. In Scene VII, the Sufi symbol of a spiral is used to show spiritual ascension. The group of people move in a spiral to reach the peak, as they sing rather than chant. The Five Robed Members of the dhikir group probably represent the five pillars of Islam. 
Dolah's story of the traveller in Scene XXI, alludes to the story of the Holy Prophet's own hijrah. He migrates (hijrah) by leaving his village to start a new life and crosses the river to help build a mosque, traveling through life with knowledge. As the Holy Prophet was reported to have said, "He who builds a mosque for Allah, Allah would build him a house in Paradise like it" (Sahih Muslim, Chapter MCCXIX: 1853). It signifies Dolah's purity of intention, another step towards the tower, towards his return to Allah SWT, completing Noordin's cycle of Theatre of Faith.

\section{DISCUSSION}

Dolah's first wrong step of "asking for help from the unseen" leads to a cascade of other causes and effects. This affirms what al-Faruqi explains under the principle of unity of Allah SWT that, "To be a Muslim is to have Allah SWT constantly present in one's consciousness" (1989: 35). Noordin tells the story of one man (Dolah) who makes the wrong choices and does evil unto himself and others around him. The message that Noordin seems to convey is that if man turns away from the unity of Allah SWT by associating Allah SWT with a partner, the consequence is vicious. The social environment or civilization is created by the way human beings act. The natural environment reacts to the way humankind treats the earth. Human beings are created by Allah SWT "out of an extract of clay (water and earth)" (Surah al-Mu'minun 23:12). Disregard for earth is like disrespect for one's own being.

Through the mistakes made by the characters, Noordin demonstrates that the wrong choices made by humankind can lead to self-destruction as well as destruction of the environment and the human race. The play goes to the root of the first principle of the unity of Allah whereby man has to believe in the Oneness of Allah SWT to safeguard the other principles of unity. To guarantee the unity of creation and life means to ensure that life comes round in a complete cycle to begin another cycle. The extinction of animal or human species or destruction of the earth means the disruption of this cycle, which means breaking the al-amanah. When this happens, the role of humankind as vicegerents has failed. Noordin warns of the abuse of free will endowed by Allah SWT through the wrong choices made by Dolah. Yet, he balances these negative choices with characters that make the right choices in life. Noordin echoes al-Faruqi in his message that the key in attaining this is to be dutiful to Allah SWT and only Him. 
The greatest test of humanity is to discover a balance between thinking and action. The cause of one's action is foolish when it is without thought. If Dolah had faith in Allah SWT no harm would have come to him, his child and the people in the village. The finality is in the unity of truth and unity of knowledge, without which, man continues to lead life in ignorance. Man's intellect, an endowment from Allah SWT, gives him the right to choose but often, Man does not use this privilege wisely. Dolah's repentance is the cycle of life as conceived in Noordin's Theatre of Faith where Dolah returns to his Creator because of his inherent fitrah. Belief and faith in Allah SWT is inherent in every human being. Man then travels with knowledge, through good deeds and 'ibadah beginning with the right intention (niyah), trust and faith in Allah SWT. The belief in the Oneness of Allah SWT, the relationship between human beings, the care shown to nature and the obligation of every Muslim to acquire wisdom through knowledge.

Human beings are equal except in their deeds that distinguish them in moral virtue, in cultural achievement and the development of civilization. This puts human beings constantly under trial in this world. To pass all tests, humankind must learn his practical limitations. By so doing, he can save himself from all misapprehensions, and can exercise his free will in the sphere of reality. He must accept restrictions in an atmosphere of freedom. Dolah has to learn not to expect rewards of this earth for helping his people; that when his intention is right, then, Allah SWT rewards.

The destruction of the earth, which violates the unity of creation is not limited to the rivers and plants but also to the human race; what is more evident in " 1400 " is the desecration of the river and the disfigured villagers. Humankind has to fight against his capacity to destroy nature, against the arrogance of power if he succeeds and against tragedy whereby despair overtakes him if he fails. Noordin's objective is to create an awareness of choices which are often wrong and most often unknowingly made due to humankind's self-interest and lack of knowledge.

The results of not having knowledge and hence not knowing the truth eventually end disastrously for characters like Dolah. Noordin stresses the importance of knowledge through the characters of Intan Siti Rahimah who sees the truth, as they have knowledge. The penetration of knowledge passes the threshold of normal acquisition of learning and touches the heart. This is especially true in accepting revealed knowledge as irrevocable and acquiring knowledge that is guided by the Qur'an. 
Humankind is endowed with the capacity to acquire this wisdom with guidance through revelation (wahy) and reason ('aql). Often, knowledge is self-evident, acquired through common experiences and when one uses reason. Reality must be seen as it is, not by what one hopes for. Unfortunately, Dolah had to see the deformity in his child to see the damage he has done before he repents. In accepting that this country belongs to other races as well, the Malays must work equally hard to retain their rights and improve their economic position. Thus, knowledge is important as it will assist mankind to make the right choices and decisions based on revelation and reason. This knowledge will then contribute to the unity of life. Only then will the patterns (sunan) of Allah's creation be continued with honour as man leads his life as true vicegerents of Allah SWT.

To the writer, Noordin, it is love and faith that determine the fate of humankind; love for oneself, one's fellow beings, one's country and faith in Allah SWT. In supporting the ideal situation of a multi-racial country, Noordin is subscribing to the principle of the unity of humanity. The tolerance of Islam towards other races and religion is propagated. The right intention (niyah) is most important to Noordin. In "1400", Dolah's intention of helping the people becomes questionable when he expects to be rewarded for it. When man does not listen to the heart it means he is not listening to what is inherent in him, that is, faith. Humankind must listen to his heart which acts as his spiritual guide, that helps him make the right choices in life. The play demonstrates these negative elements through Dolah's choice which is based on envy. Without guidance and knowledge, diseases of envy, greed, anger and lust can grow in one's heart.

\section{CONCLUSION}

The characters portrayed in the play lead the audience to see that what really distinguishes one man from another is character. A person's superiority can therefore be seen only in terms of the degree to which he is honourable. The truly honourable human being is one who recognizes and fulfils his duty to Allah SWT and respects the rights of his fellowmen as can be seen from the roles portrayed by the protagonists in the plays. The antagonists highlight the dishonourable characteristics of humankind. The divine trust (amanah) is man's reason for existence, to fulfil the divine will through free will. It is therefore the duty of man to develop and establish a culture and civilization in line with the goal of the divine trust. Only then will human 
beings succeed as vicegerents; through defining and applying the relevance of Islam in living life.

Obviously Noordin believes Islam to be the truth and and that he has to carry the message of Islam through his plays. More than a mission, Noordin has made it his taklif (responsibility or obligation). The difference is the means and manner that Noordin uses to propagate Islam, which is through drama. The duty that Noordin has entrusted himself with is the dissemination of "wisdom" that "appeals to the feeling" of the reader (and the audience) in the "gracious manner" of theatre. He has made it his duty, as it is the duty of every Muslim to seek knowledge in acquiring wisdom: wisdom within himself, wisdom for other Muslims, wisdom for the world at large. This, according to Noordin, can be achieved when the audience thinks and reasons for himself, as thinking brings wisdom and change from within, that is when the conscience is pierced.

\section{NOTES}

1. Surah al-Baqarah, al-'Imran, an-Nisa', al-Ma'idah, al-An'am, al-A 'raf, at-Taubah, Maryam, al-Anbiya', al-Hajj, al-Mu'minun, an-Nur, an-Naml, ar-Rum, Luqman, alAhzab, Fussilat, al-Mujadilah, al-Muzzammil, an-Naba'.

2. Researcher's translation.

\section{REFERENCES}

Aasi, Ghulam Haider, 2004. Muslim Understanding of Other Religions. New Delhi. Adam Publishers \& Distributors.

'Abdul Hamid Siddiqi (trans.), 2000. Șahīḥ Muslim. New Delhi: Kitab Bhavan. Abdullah Yûsuf Ali (trans.), 1946. The Holy Quran, R.S.A.: Islamic Propagation Centre International.

Absar Ahmad, 1992. Qur'anic concepts of human psyche. In Qur'anic Concepts of Human Psyche. Zafar Afaq Ansari (ed.). Lahore: International Institute of Islamic Culture.

Al-Attas, Syed Muhammad Naquib, 1984. Islam, Secularism and the Philosophy of the Future. London \& New York: Mansell Publishing Limited.

Al Fārūqī, Ismail R. and al Fārūqī, Lois Lamya, 1986. The Cultural Atlas of Islam. New York: Macmillan Publishing Company.

Al-Faruqi, Ismail Raji, 1989. Islamization of Knowledge, General Principles and Work Plan. Herndon: International Institute of Islamic Thought. 
Al- Faruqi, Ismail Raji, 1992. Al Tawhid. 2nd edition. Herndon: International Institute of Islamic Thought.

Al-Hilali, Muhammad Taqi-ud-Din \& Muhsin Khan, Dr. Muhammad (trans.), (n.a.). The Noble Qur'an in the English Language. Dr. King Fahd Complex KSA: Islamic University of Al-Madinah Al-Munawwarah.

Al-Qaradawi, Yusuf, 2001. The Lawful and the Prohibited in Islam. Kuala Lumpur: Islamic Book Trust.

'Alwānī, Tāhā Jābir, 1995. The Islamization of Knowledge: Yesterday and Today. Herndon: International Institute of Islamic Thought.

Cawley, .A.C., (ed. and intro), 1959. Everyman and Medieval Miracle Plays. New York: E.P. Dutton \& Co. Inc.

Dar Al-Kotob Al-Ilmiyah. Arabic-English Dictionary. Lebanon. 1421/2001 A.D.

Faizal Yamimi Mustaffa (trans.), "Theatre of faith" in Malay Literature Vol. 81995.

Faizal Yamimi Mustaffa (trans.), 1998. "1400” in Malay Literary Laureates. Kuala Lumpur: Dewan Bahasa dan Pustaka.

Guerin, Wilfred L., Morgan, Earle, Labor Lee, Willingham, John R., 1979. A Handbook of Critical Approaches to Literature. 2nd edition. New York: Harper \& Row Publishers Inc.

Halverson, Marvin (selection and intro.), 1964. Religious Drama 3. 4th edition. New York: Meridian Books.

Hawa Abdullah (trans.), "Noordin Hassan: Speech on Receiving the Seventh National Literary Award" in Malay Literature 8:2, 1994.

Kementerian Kebudayaan, Kesenian dan Pelancongan Malaysia (1/2003). Umi Abdullah (ed.). Siri Mengenali Budaya: Wayang Kulit. Kuala Lumpur: Perpustakaan Negara Malaysia.

Kementerian Kebudayaan, Kesenian dan Pelancongan Malaysia (1/2003). Umi Abdullah (ed.). Siri Mengenal Budaya Makyung. Kuala Lumpur: Perpustakaan Negara Malaysia.

Malini Das (ed.), 2002. Glimpses of Old Penang in Conjunction with the 30th Anniversary of Star Publications (M) Bhd. Penang: Star Publications (M) Bhd.

Maulana Ashraf Ali Thanvi, 2003. Âadâbul Mu'âsharat (Etiquettes of Social Life), Delhi: Rightway Publications.

Metzger, B.M. \& Coogan, M.D. (eds.), 2002. The Oxford Essential Guide to Ideas \& Issues of the Bible. New York: Berkley Books.

Muhammad Muhsin Khan (ed.), 1986. Sahih al-Bukhari. 6th edition. Lahore: Kazi Publications.

Noordin Hassan, "Speech on Receiving The Seventh National Literary Award" in Malay Literature 8:2., 1995.

Noordin Hassan, 1996. Saya Dari ... Hujung Kota. Kuala Lumpur: Dewan Bahasa dan Pustaka.

Noordin Hassan, 1997a. Peran - Kumpulan Drama. Kuala Lumpur: Dewan Bahasa dan Pustaka. 
MALAY LITERATURE VOLUME 29 NUMBER 2 DECEMBER 2016

Noordin Hassan, 1997b. Sirih Bertepuk Pinang Menari. Kuala Lumpur: Dewan Bahasa dan Pustaka.

Noordin Hassan, 2000. Mana Setangginya? Kumpulan Drama Pilihan. Kuala Lumpur: Dewan Bahasa dan Pustaka.

Noordin Hassan, 2002. "Inti pati falsafah teater fitrah" in Teater Fitrah dan Esei Pilihan Noordin Hassan. Kuala Lumpur: Dewan Bahasa dan Pustaka.

Penerbit Fajar Bakti Sdn. Bhd. (A subsidiary of Oxford University Press, 2005. Kamus Bahasa Melayu-Bahasa Arab. Shah Alam.

Saniyasnain Khan, 2002. Presenting the Qur'an. New Delhi: Goodword Books.

Received: 29 June 2016

Accepted: 21 November 2016 